\title{
A Postmodernist Reading of Sam Shepard's True West
}

\author{
Abdol Hossein Joodaki (Corresponding author) \\ Dept. of English, University of Lorestan, Khorramabad, Iran \\ E-mail: Joodaki367@yahoo.com \\ Samaneh Shooshtarian \\ University of Lorestan, Khorramabad, Iran
}

Received: 11-05-2013

doi:10.7575/aiac.ijalel.v.2n.5p.201
Accepted: 08-07-2013

Published: 01-09-2013

URL: http://dx.doi.org/10.7575/aiac.ijalel.v.2n.5p.201

\begin{abstract}
This paper attempts to render some vivid postmodernist features in Shepard's True West (1980), which is inspired by myths of American life and popular culture. Shepard's True West suggests so many interesting postmodern elements. With a departure from conventional norms of character, dialogue and narrative; the elements of pastiche, subjective irony, and savage humor have become hallmarks of most of his works. These features and some of the basic traces of postmodern literature, including Lyotard's theory of the end of meta-narratives and language game, Derrida's deconstruction and Baudrillard's simulation, as well as language fragmentation, uncertainty and duality, altogether, have given Shepard's True West a postmodern atmosphere.
\end{abstract}

Keywords: Postmodernist Literature; Grand Narratives; Duality; Self Reflexivity; Language Game; Binary oppositions; Simulacrum

\section{Introduction}

This paper attempts to render a postmodernist reading of Sam Shepard's family play True West (1980). The study starts with a very brief introduction of True West. Then, it is followed by its postmodernist analysis of the play within a postmodernist frame, in which the theories of the three French philosophers, Jean- François Lyotard, Jean Baudrillard and Jacques Derrida, are taken into account.

\section{TRUE WEST: A QUICK SURVEY}

Although it did not receive an outstanding award, as Buried Child won Shepard the Pulitzer Prize for Drama in 1979, True West (1980) has arguably become his signature and, according to many critics, it remains the most praised Shepard's play in American theatres.

The story of the play can be regarded as an essential expression of Shepard's vision, investigating the main concerns of his career: masculinity, West identity, and the individual's attitude toward communal relations.

True West is regarded as Shepard's signature as, according to him;

This is the first one of my plays I've been able to sit through night after night and not have my stomach ball up in embarrassment ... I've worked longer on this than any other play. I rewrote it thirteen times. True West is the first play I've truly lived up to. (qtd. in Mcteague 1996, p. 107)

In an article assembled by Robert Coe for The New York Times Magazine in 1980, Sam Shepard maintained that for him "we're split in a much more devastating way than psychology can ever reveal" and disclosed that with True West he "wanted to write a play about double nature" (qtd. in Wade 1997, p. 103).

Shepard wrote the play during or after a stay at his mother's home in Pasadena in August 1979, and it is set in "a kitchen and adjoining alcove of an older home in Southern California suburb, about 40 miles east of Los Angeles" (True West 3). The title of the play refers to a Western-oriented pulp magazine of the same name, a choice that, according to Wade, "may initially suggest an attitude toward the West that is more parody than endorsement" (p. 294).

The two-character play, True West, is about two brothers, Austin, a Hollywood screenwriter, and Lee, a loner and a thief who lives in desert. Their mom is spending vacation in Alaska and their father is totally absent. The play establishes the brother's comparison and contrast: Austin represents the social order, while Lee represents the wild of nature. Both brothers look for something as they feel a lack, both dream of a 'thing' that will fulfill them, and toward the end of the play it is, in fact, the life-style of the other brother that will serve as this longed-for fulfillment. Meanwhile, Andreach (1998) analyzes the play within familial context "with the parents separated, the burden of reconciling the family, and perhaps healing it in resolution, falls on the shoulder of the offspring" (p. 178).

Austin's control over the house is demolished by the uninvited invasion of his brother, who brings chaos with him. The fundamental dramatic tension begins when Lee comes between Austin and the film producer, Saul Kimmer, who has been supporting a project written by Austin. Lee, in fact, divers Austin's project and sells Saul his own story, that of a 
'contemporary Western', one that would be "true to life” (Shepard 1981, p. 42). The tension becomes harsher as Lee that is not able to put his ideas into script, breaks down the typewriter and begs Austin's assistance. This struggle produces a great deal of accusations and confessions and finally draws the brothers into a strange intimacy; Lee will take Austin to desert if he helps him in writing the scenario. As a result, both men's personas are portrayed as "unstable compositions of shifting, conflicting desires, devoid of any reliable sense of self and thus capable of volatility" (Bottoms 1998, p. 195).

It is true that the two brothers shift roles, Lee becomes Austine, and vice versa, yet they were a fake from the start.

AUSTIN: (moves back into alcove) All right. Take it easy.

LEE: I'm gonna' be leavin' this area. I don't have time to mess around here.

AUSTIN: Where are you going?

LEE: Never mind where I'm goin'! That's got nothin' to do with you. I just gotta' get this done. I'm not like you. Hangin' around bein' a parasite offa' other fools. I gotta' do this thing and get out.

(pause)

AUSTIN: A parasite? Me?

LEE: Yeah, you!

AUSTIN: After you break into people's houses and take their televisions?

LEE: They don't need their televisions! I'm doin' them a service.

AUSTIN: Give me back my keys, Lee.

LEE: Not until you write this thing! You're gonna' write this outline thing for me or that car's gonna' wind up in Arizona with a different paint job. (Shepard 1981, p. 24)

While Lee was unable to live in the desert like his father, Austin has abandoned his wife, his kiddies, and "the whole slam". They were not that different. Indeed, the reversal of roles only serves to disclose their similarities. After all, neither of them was the person he pretended to be. The opening lines of the play unveil that the two brothers seem to have returned to their infancy in the playground of their childhood years:

LEE: So, Mom took off for Alaska, huh?

AUSTIN: Yeah.

LEE: Sorta' left you in charge.

AUSTIN: Well, she knew I was coming down here so she offered me the place.

LEE: You keepin' the plants watered?

AUSTIN: Yeah.

LEE: Keepin' the sink clean? She don't like even a single tea leaf in the sink ya' know.

AUSTIN: (trying to concentrate on writing) Yeah, I know.

(pause)

LEE: She gonna be up there a long time?

AUSTIN: I don't know.

LEE: Kinda' nice for you, huh?Whole place to yourself. (Shepard 1981, p. 42)

In fact, the dichotomy between Austin and Lee represents the dichotomy between civilization and wildness. Throughout the play, there would be a constant question in the reader's mind; which brother's perspective can be really seen as representative of today's 'true west'? Perhaps none of them! And it is so interesting that the destruction of stable identity in True West is mirrored by the destruction of the stage spaces, which seem to be representative of the state of their residents' souls.

\section{TRUE WEST: TRAPPED IN POSTMODERNITY}

The term postmodernism, by itself, has been overloaded with meanings. Among these overloaded meanings, however, three various uses of the term may widely be identified:

First, postmodernism represents a number of developments in the arts and culture in the latter half of the twentieth century. The reference point and point of departure for this type of postmodernism are the different forms of modernism that developed in the arts and culture in Europe in the first half of the century. Second, it designates the rise of new frameworks of social and economic organization, again approximately since the end of the 1939-45 war. As such, its reference point and point of departure is the tendency of modernization which specified the early years of the century, with the development of industry, the growth of the mass market, and the speed in automation, travel and mass communication. Third, it indicates a peculiar type of theoretical writing and reflection, usually though not completely, 
writing and reflection which chooses the first or second area as its goal. (Hooti and Shooshtarian 2010, p.14)

However, in relation to literature, in general, and in drama, in particular, the term would have a wide range of specific characteristics. As Saddik (2007) states:

Characteristics of postmodern literature and drama include a focus on the instability of meaning and the inadequacy of language tocompletely and accurately represent truth, along with an irony and playfulness in the treatment of linguistic constructs. (p. 6)

And, according to Lewis (2001);

Some of the dominant features of postmodernist fiction include: temporal disorder; the erosion of the sense of time; a pervasive and pointless use of pastiche; a foregrounding of words as fragmenting material signs; the loose association of ideas; paranoia; and vicious circles, or a loss of distinction between logically separate levels of discourse. (p. 123)

With a departure from conventional norms of character, dialogue and narrative; the elements of pastiche, subjective irony, and savage humor, as well as other characteristics mentioned by the world's great postmodernist thinkers, Shepard's True West follows the basic tenets of postmodern literature.

As the play unfolds, the situation of characters becomes more complex and ambiguous, showing a degree of "semantic indeterminacy that is the frequent hallmark of postmodernist aesthetic production" (Murphy 1992, p. 187). They do not understand each other even by the time they are talking about usual events.

AUSTIN: (stops typing) Come on, Lee.

(AUSTIN gets up, moves to kitchen, gets a glass of water)

LEE: Whadya' mean, "come on"? That's what it is. Write it down! He's runnin' outa' gas.

AUSTIN: It's too--

LEE: What? It's too what? It's too real! That's what ya' mean isn't it? It's too much like real life!

The play's plot development appears logical on the surface, but it gradually becomes completely disorienting. Tensions at work in the play generally represent; (Shepard 1981, p. 63)

According to Bottoms:

an unresolved conflict between modernist and postmodernist perspectives on such issues as the nature of self-identity, the search for coherence and meaning in late capitalist culture, and the creative process itself. (1998 p. 13)

Through the course of the play, Austin and Lee, two feuding brothers, are in search of their identities and their past in a 'modern' sense, ignoring the fact that past and all its ideals are gone with the wing and a new postmodern atmosphere is in the air.

\section{TRUE WEST: THE FALL OF GRAND NARRATIVES}

With the publication of Lyotard's report on knowledge, The Postmodern Condition, in 1950s, the picture of postmodern studies was completed. This bible of postmodern movement, by Lyotard, rejects legitimation in the Enlightenment, called metanarratives or grand narratives. Metanarratives are total philosophies of history setting out the rules of narratives and language games, which establish ethical and political rules for the society.

Throughout history, Lyotard argues, society has been founded upon metanarratives which legitimate the social bond and the relationship of science and knowledge to it. These metanarratives (Marxism, Liberalism, Fundamentalism, the progress of Man) are stories or principles that give credibility to a society and justify its actions and visions of the future. (Walmsley 2005, p. 412)

According to Lyotard (1984), these metanarratives that traditionally used to give cultural paradigms, some forms of legitimation or authority, have "lost their credibility" since the Second World War and notes the idea that "Simplifying to the extreme, I define postmodern as incredulity towards metanarratives"(p. xxiv) and, "postmodern Knowledge is not simply a tool of the authorities; it refines our sensitivity to differences and reinforces our ability to tolerate the incommensurable" (p. xxv)

The postmodern condition, as Lyotard defines it, is the state of disillusionment with such metanarratives. No system and no metanarrative is all-inclusive and universal. The outcome of this incredulity toward metanarratives is what Lyotard calls "delegitimation", the process by which metanarratives lose their power to legitimize discourses. According to Lyotard: 
In contemporary society and culture - postindustrial society, postmodern culture -

the question of the legitimation of knowledge is formulated in different terms. The

grand narrative has lost its credibility, regardless of whether it is a speculative narrative

or a narrative of emancipation. (1984 p. 37)

Exhibiting a postmodern suspicion that the redemptive powers of modernism's paradigms might in fact be futile, Shepard's play represents the Lyotardian breakdown of grand narratives.

The central action in True West, generally, is a confrontation between sons' outdated reliance on absolutes, on codes of behavior, and on grand narratives. True West seems to portray the situation of cultures after the end of 'grand narratives' which in modernism were providers of guidelines for societies.

In this play, Austin and Lee yearn for a center; sometimes this center is supposed to be their father, and sometimes it is the comfort of desert which can give them the true touchstone. But the fact is that, there is no longer any center to stick to; everything is so unreliable because there is no real authority and no final meaning; no transcendental signified.

AUSTIN: What kind of a place was it?

LEE: Like a paradise. Kinda' place that sorta' kills ya' inside. Warm yellow lights. Mexican tile all around. Copper pots hangin' over the stove. Ya' know like they got in the magazines. Blonde people movin' in and outa' the rooms, talkin' to each other. (pause) Kinda' place you wish you

sorta' grew up in, ya' know.

AUSTIN: That's the kind of place you wish you'd grown up in?

LEE: Yeah, why not?

AUSTIN: I thought you hated that kind of stuff.

LEE: Yeah, well you never knew too much about me did ya'? (pause)

AUSTIN: Why'd you go out to the desert in the first place?

LEE: I was on my way to see the old man.

AUSTIN: You mean you just passed through there?

LEE: Yeah. That's right. Three months of passin' through.

AUSTIN: Three months?

LEE: Somethin' like that. Maybe more. Why?

(Shepard 1981, p. 11)

In stark contrast to structuralism (which is a branch of modernism) in which every signifier has a signified, in postmodernism there is no final signified and therefore no final truth. The sense of bewilderment which is felt by Austin and Lee is exactly due to not being able to find a final signified which can give their life a true meaning. It seems that Austin and Lee are ritualistically searching for a lost place. According to Wilcox (1984), what, in fact, they are searching for is "an absent center in the narrative of the play's action, for some overriding structure in the narrative of their own existence" (p. 561).

But as Wilcox continues;

In the post-historical space of the play, the master narratives no longer provide structure in the midst of linguistic fragmentation; they no longer "share up the ruins" in any modernist sense nor provide a grounding for social or individual identity" (ibid).

Interestingly, in Lee's western scenario the search for final signified is completely visible as the two lamebrains are trapped within an everlasting cycle of chasing, without having any privilege over each other. The reason of Lee's success regarding his scenario over Austin's may be the fact that his 'true western' is both unbelievable and realistic. At the same time, Austin's story of their father losing his dentures is totally true and in fact has the "ring of truth" (Shepard 1981, p. 35). The reason of this actuality is "precisely because it seems so bizarre that nobody would dare to make it up. What, then, constitutes the 'truth'? No transcendental signified!” (Bottoms 1998, p. 206)

\section{TRUE WEST: SIMULACRUM}

The postmodern world, according to Jean Baudrillard, is a world in which the model of production has been replaced by the cybernetic model of simulation, a "cybernetization" of society.

Baudrillard defines the simulacrum, quite simply, as a copy or reproduction of the real, and traces the steps by which it progressively assumes an autonomous status, divorced from the real. It is the reflection of a basic reality. It masks and perverts a basic reality. It masks the absence of a basic reality. It bears no resolution to any reality whatever: it is its own pure simulacrum. (Taylor and Winquist 2001, p. 367) 
'True west' is in fact a place in which the brothers can find an authority or a final signified for their empty lives. Austin and Lee are searching for their true identities, their true selves they have lost years ago. Having lost their true identities, their roles in society do not satisfy them; so they change roles. Austin, the screenwriter becomes a thief and a constant drunkard, and Lee, the loner and the robber tries being a screenwriter.

LEE: I'm a screenwriter now! I'm legitimate.

AUSTIN: (laughing) A screenwriter!

LEE: That's right. I'm on salary. That's more'n I can say for you. I got an advance coming.

AUSTIN: This is true. This is very true. An advance. (pause) Well, maybe I oughta' go out and try my hand at your trade. Since you're doing so good at mine.

LEE: Ha!

(LEE attempts to type some more but gets the ribbon tangled up, starts trying to rethread it as they continue talking)

AUSTIN: Well why not? You don't think I've got whatit takes to sneak into people's houses and steal their T.V.s?

LEE: You couldn't steal a toaster without losin' yer lunch.

(AUSTIN stands with a struggle, supports himself by the sink)

AUSTIN: You don't think I could sneak intosomebody's house and steal a toaster?

LEE: Go take a shower or somethin' will ya!

(LEE gets more tangled up with the typewriter ribbon, pulling it out of the machine as though it was fishing line)

AUSTIN: You really don't think I could steal a crumby toaster? How much you wanna' bet I can't steal a toaster! How much? Go ahead! You're a gambler aren't you? Tell me how much yer willing to put on the line. Some part of your big advance? Oh, you haven't got that yet have you. I forgot. (Shepard 1981, p. 40)

In this way, they copy, or, in other words, reproduce themselves. Again, no satisfaction is achieved, why? The answer is a postmodern pessimist acceptance that self is all style and surface, a simulacrum. Thus, Austin and Lee's old and new roles are all simulacrum, and search for the true self is, in fact, impossible.

\section{TRUE WEST: DEFERRING COMPLETENESS AND CLOUSURE}

"The ending of all of the Victorian works are 'closed' while, the ending of modernist works are 'open'. The endings of postmodernist works are a hybrid of these two." (Hooti \& Shooshtarian 2010, p. 22). In postmodern plays endings are "both open and closed" because they are "either multiple or circular". As McHale claims:

Endings constitute a special case of self-erasing sequences, since they occupy one of the most salient positions in any text's structure. Conventionally, one distinguishes between endings that are closed, as in Victorian novels with their compulsory tying-up of loose ends in death and marriage, and those that are open, as in many modernist novels. But what are we to say about texts that seem both open and closed, somehow poised between the two, because they are either multiple or circular. (1987 p. 109)

Deferring completeness is, then, what happens in True West. Immediately after Mom's exist, True West ends, without completing the play or coming to a resolution.

MOM: I can't stay here. This is worse than being homeless.

AUSTIN: I'll get everything fixed up for you, Mom. I promise. Just stay for a while.

MOM: (picking up luggage) You're going to the desert.

AUSTIN: Just wait!(LEE thrashes, AUSTIN subdues him, MOM watches holding luggage, pause)

MOM: It was the worst feeling being up there. In Alaska. Staring out a window. I never felt so desperate before. That's why when I saw that article on Picasso I thought-

AUSTIN: Stay here, Mom. This is where you live. (she looks around the stage)

MOM: I don't recognize it at all.(she exits with luggage, AUSTIN makes a move toward her but LEE starts to struggle and AUSTIN subdues him again with cord, pause)

(Shepard 1981, p. 63)

Sons are unable to escape to the desert, yet unable to finish off their sibling rivalry. Not only the ending, but the whole play, is full of holes and contradictions that the audience can't just fill in the story, in fact, comes to no closure since 
there are no telos or predetermined points of closure. The writer, also, has no final authority over the sibling rivalry or it is better to say over the text, as Austin and Lee continue fighting each other and the stage becomes darkened.

\section{TRUE WEST: LANGUAGE GAMES}

In Lyotard's work, the term "language game", a term he draws from the highly influential Austrian philosopher Ludwig Wittgenstein, which is sometimes called "phrase regimens" indicates the multiplicity of communities of meaning, the innumerable and countless systems in which meanings are produced and rules for their circulation are created. In other words, language game is the system of rules and conventions which frame and govern a particular discourse and as Mason (2007) explains:

"positive knowledge" can be created by a reunification of cognitive and practical knowledges in the form of "paralogy" which privileges the creation of small narratives that do not aspire to the totalizing imperative of the grand narrative. These types of knowledge, which Lyotard also refers to as "language games," admit to their provisionality and offer local open-ended knowledges that can be developed according to the conditions of the practical knowledge that they encounter. (p. 191)

Accordingly, when there are not any sub narratives, everyone applies his own language game according to his age, profession and status in the society. So, the self and identity become nothing more than the layers that society has imposed on one's personality. This kind of imposing and the practice of language game is completely reviewed by Shepard in True West.

The play repeatedly betray a suspicion that personal identity might consist of no more than the sum of one's culturally imposed layers, and that only through the outward performance of a desired self-image can one achieve any sense of distinct being. Such performativity apparently constitutes the only "truth" in a postmodern culture which - according to Jean-Francois Lyotard - now functions entirely according to the interplay of self-legitimating, self-perpetuating "language games". (Bottoms 1998, p. 123)

Language games, most of the time, result in lack of understanding. In True West, the language game of Austin and Lee is completely different from each other. Even Austin and his producer, Saul Kimmer, who at first appear to share some common ground Austin's project, have completely different language games.

LEE: Now you tell him. You tell him, Mr. Kipper.

SAUL: Kimmer.

LEE: Kimmer. You tell him what you told me. He don't believe me.

AUSTIN: I don't want to hear it.

SAUL: It's really not a big issue, Austin. I was simply amazed by your brother's story and--

AUSTIN: Amazed? You lost a bet! You gambled with my material!

SAUL: That's really beside the point, Austin. I'm ready to go all the way with your brother's

story. I think it has a great deal of merit.

AUSTIN: I don't want to hear about it, okay? Go tell it to the executives! Tell it to somebody who's going to turn it into a package deal or something. A T.V. series. Don't tell it to me.

SAUL: But I want to continue with your project too, Austin. It's not as though we can't do both.

We're big enough for that aren't we?

AUSTIN: "We"? I can't do both! I don't know about "we." (Shepard 1981, p. 34)

Due to this reason (different language games) Austin feels bewildered why Saul does not back his project any more. The fact is that, in Saul's language game there is no place for commitment and promise; the components of his language are perhaps gaining more money and getting more prosperous in the field of business.

\section{TRUE WEST: LANGUAGE FRAGMENTATION}

Linguistic fragmentation is another distinctive element of postmodern drama which is rooted in the lack of understanding just discussed. Lack of understanding gradually results in lack of conversation and all these, again, are rooted in 'problems of language'. Postmodern language is fragmented. Regarding this point, Wilcox (1984) notes:

In Shepard's world of pop bricolage each individual speaks in a private code or idiolect, and becomes a kind of linguistic island separated from everyone else. (p. 561)

Shepard's use of pauses and lengthy dialogues in True West perhaps highlights lack of true communication and conversation. 
AUSTIN: (struggles to stand again) She's five hundred miles away. North. North of here. Up in the North country where things are calm. I don't need any help. I'm gonna' go outside and I'm gonna' steal a toaster. I'm gonna' steal some other stuff too. I might even commit bigger crimes. Bigger than you ever dreamed of. Crimes beyond the imagination!

(AUSTIN manages to get himself vertical, tries to head for exit again)

LEE: Just hang on a minute, Austin.

AUSTIN: Why? What for? You don't need my help, right? You got a handle on the project. Besides, I'm lookin' forward to the smell of the night. The bushes. Orange blossoms. Dust in the driveways. Rain bird sprinklers. Lights in people's houses. You're right about the lights, Lee. Everybody else is livin' the life. Indoors. Safe. This is a Paradise down here. You know that? We're livin' in a Paradise. We've forgotten about that. (Shepard 1981, p. 41)

There are meaningful pauses in the play's conversations and the reader is right in feeling tension during the silent moments. In other words, pauses function to underline lack of real communication between Austin and Lee and through this creates tension in the play. A prime example of this case can be represented in the first scene of the play:

The brothers say very little of any substance to each other: the dialogue is quiet, desultory, and coyly amusing, and both are at times reduced to guttural grunts of 'uh' when communication escapes them. A subject is raised, then dies, then a new one is introduced. (Bottoms 1994, p. 189)

\section{TRUE WEST: UNCERTAINTY}

Pervasive uncertainty is one of the key elements of True West's dramatic world. Austin and Lee suffer from deep anxieties regarding the direction and meaning of their lives as well as the world around them. Both have a longing for confidence and confirmation. In the course of the play, Austin, became uncertain about his nature, is made aware of the fact that he has suppressed his 'masculine' qualities which were drummed into him during to his upbringing, an inheritance he has sought to deny by cutting himself from his father. His brother, Lee, also, like Tilden in Shepard's Buried Child (1978), cannot really survive in the wild, and needs to have human company and some sense of stability. As a result, both men's personas are portrayed as uncertain characters and as Bottoms (1998)describes: "unstable compositions of shifting, conflicting desires, devoted of any reliable sense of self and thus capable of volatility" (p.195).

AUSTIN: Blondes? That's funny.

LEE: What's funny about it?

AUSTIN: Because I always used to picture you somewhere.

LEE: Where'd you picture me?

AUSTIN: Oh, I don't know. Different places. Adventures. You were always on some adventure.

LEE: Yeah.

AUSTIN: And I used to say to myself, "Lee's got the right idea. He's out there in the world and here I am. What am I doing?"

LEE: Well you were settin' yourself up for somethin'.

AUSTIN: I guess.

LEE: We better get started on this thing then.

AUSTIN: Okay. (Shepard 1981, p. 28)

\section{TRUE WEST: SELF-REFLEXIVITY OF THE TEXT}

Theatre, in general, is less reliant on words than is fiction; it mostly focuses on the images and representations. The theatre of images, according to Murphy (1992) "carries postmodern self-reflexivity to one logical extreme: it re-present nothing but itself and demands only that we submit ourselves to its seductive spectacularity" (p.194). However, selfreflexivity and meta-discursivity with which a text displays and deconstructs the processes of its own signification are considered as two common features of postmodern drama.

In the course of the play, Lee's story of the two lamebrains implicitly portrays the brother's own situation; thus in a postmodern sense, the story represents nothing but itself. This technique, used by Shepard in True West is in fact "a self-deconstructing device which is indeed one of his most original devices on the theme of characters being trapped within textuality" (ibid 193). Through this device, the playwright undermines the illusion of the characters' existence supposing themselves as self-present beings. Therefore, Shepard narrates them as fragmented, flowing, and uncertain identities whose exact locations and boundaries cannot be demonstrated.

AUSTIN: (laughs) You're tryin' to concentrate?

LEE: Yeah. That's right.

AUSTIN: Now you're tryin' to concentrate. 
LEE: Between you, the coyotes and the crickets a thought don't have much of a chance.

AUSTIN: "Between me, the coyotes and the crickets." What a great title.

LEE: I don't need a title!I need a thought.

AUSTIN: (laughs) A thought! Here's a thought for ya'--

LEE: I'm not askin' fer yer thoughts! I got my own. I can do this thing on my own.

(Shepard 1981, p. 38)

\section{TRUE WEST: DUALITY}

True West, in general, seems to be a kind of duel, in which characters at times treat each other violently; so the play demands more action and physicality than Shepard's earlier plays. Austin and Lee are bound together in dualistic, complementary pairs. In the course of the play, each character seems to represent one side of a double-headed coin, but as it is a Shepard's work, this duality does not lead to a healthy manner, rather to a constant division. As Bottoms (1998) notes; "these pairings are both interdependent and self-destructive caught in an impossible bind of mutual incompatibility" (p. 191). Regarding the play, Shepard has been reported that:

I just wanted to write a play about double nature, one that wouldn't be symbolic or metaphysical or any of that stuff. I just wanted to give a taste of what it feels like to be two-sided. It's a real thing, double nature. I think we're split in a much more devastating way than psychology can ever reveal. It's not so cute. Not some little thing we can get over. It's something we've got to live with. (qtd. in Bottoms 1998, p. 191)

It is, also, possible to view True West as a struggle between two halves of the self;

In fact, the kind of savagery with which brothers war with each other in True West, indicates not only a deeply-rooted conflict between them, but also an equally crucial symbiosis. (Kane 2002, p. 143)

Shepard believes:

The brothers' differences are treated as surface role play, as somewhat arbitrary polarizations of behavioral characteristics, which demand the repression of any number of other free-floating possibilities. (qtd. in Shewey 2004, p. 2)

The identities of Austin and Lee are mostly dependant on a kind of mutual hatred; it is revealed that both of them have a great feeling of opposition toward each other. This opposition gradually fades away as the brothers get more intimate to each other and come to this realization that how fragile their chosen roles have been. In fact, their firm ego identities are undermined as the binaries are reversed and values are devalued. In this case, Sheila Rabillard has an interesting idea; she says:

Certainly Austin and Lee, the opposite and to some extent interchangeable brothers correspond to two sides of the Shepard known to the audience: the photogenic and much described playwright from California ... and the rough-hewn character familiar from the films he had appeared in at this point in his career. (qtd. in Wilcox 1984, p. 83)

By contrast, the brothers only repeat a self-destructive pattern that has entrapped them since childhood. They are involved in a kind of postmodern dual, the setting is their mother's house and they have no gun or wild horses. In fact, Lee and Austin face each other in a Western no-man's land. They are near the plastic city of Los Angeles, not the desert, and they have no horses to take them away. All Austin has is the cord that, according to Couch (2006) "symbolizes their unbreakable family connection with each other and his mother who flows from the scene rather than stay and resolve it" (p. 128).

SAUL: It has the ring of truth, Austin.

AUSTIN: (laughs) Truth?

LEE: It is true.

SAUL: Something about the real West.

AUSTIN: Why? Because it's got horses? Becauseit's got grown men acting like little boys?

SAUL: Something about the land. Your brother is speaking from experience.

AUSTIN: So am I!

SAUL: But nobody's interested in love these days, Austin. Let's face it.

LEE: That's right. (Shepard 1981, p.5)

As a result, all Austin and Lee have now is each other. If either of them loses the other, then the victorious one is left with nothing. All that remains for the brothers, is to remain locked in a deadlock that defers any kind of resolution and keeps them entrapped in the ever cyclic nature of their family. 


\section{TRUE WEST: BINARY OPPOSITIONS}

The main characters of the play, Austin and Lee are, certainly, the first binary opposition to be discussed if the course of the play. As the play opens, Austin, a respectable man, a screenwriter with a wife and a family is at the top of the binary. On the other hand, Lee, dramatized as a constant drunkard, a thief and a drifter, is at bottom. Later on, in their conversation, it is made clear that each of them has been to some extend jealous of the other brother's life style:

LEE:... I always wondered what'd be like to be like you.

AUSTIN: You did?

LEE: Yeah, sure. I used to picture you walkin' around some campus with yer arms fulla' books.Blondes chasin after ya'.

AUSTIN: Blondes? That's funny ... because I always picture you somewhere.

Lee: Where'd you picture me?

AUSTIN: Oh, I don't know. Different places. Adventures. You were always on adventures... And I used to say to myself, "Lee's got the right idea. He's out there in the world and here I am. What am I doing?” (Shepard 1981, p. 26)

Then, by the time Lee tries to write a 'true to life' scenario for Austin's producer, Austin goes to alcohol and theft and the role reveals happen. With this reversal, now, Lee is the one who claims to be legitimate, "I'm a screenwriter now. I'm legitimate!" (ibid p. 37). And the drunken Austin is perceived as the "intruder".

With regard to the reversal of the hierarchy, depth and surface models of personal identity, also, can be taken as another binary in True West. At first, in both brothers, the surface identity is at the top of the binary. Being a screenwriter is the surface identity of Austin, the depth of his identity has long been suppressed, but, toward the end of the play, it is the depth of his identity that comes to the top of the binary; in fact, it is his inheritance, his masculinity, which has been kept hidden, for years.

Lee's claim regarding being connected to the land and getting used to living in the desert is also the surface of his identity which at the top at the beginning of the play at the top. After his confessions, his surface identity goes to the bottom; it is revealed that Lee is living in the desert since he has not been able to make it in the town; the binary, in this case, is revealed again.

AUSTIN: You lived on the Mojave for three months?

LEE: Yeah. What'sa' matter with that?

AUSTIN: By yourself?

LEE: Mostly. Had a couple a' visitors. Had that dog for a while.

AUSTIN: Didn't you miss people?

LEE: (laughs) People?

AUSTIN: Yeah. I mean I go crazy if I have to spend three nights in a motel by myself.

LEE: Yer not in a motel now. (Shepard 1981, p. 12)

These reversals seem to continue forever, because the story comes to know closure and, therefore, the readers never come to a final signified.

The opposition between 'old west' and 'new west' is another binary of True West. Austin and Lee's mom represents the old west; a simple woman still believing in traditions, brotherhood, and family, the concepts which postmodern west lacks effectively. At the same time, it is possible to look at Austin and Lee as two versions; the 'new west' and the 'old west'. Lee's west is completely different with that of new west; his old west is characterized by images of manliness, mobility, unpredictability, rootlessness, humor and violence, while the new west consists of suburbs, freeways, toasters, color TVs and, house plants, the things which concern Austin's mind.

SAUL: Something about the real West.

AUSTIN: Why? Because it's got horses? Because it's got grown men acting like little boys?

SAUL: Something about the land. Your brother is speaking from experience.

AUSTIN: So am I!

SAUL: But nobody's interested in love these days, Austin. Let's face it.

LEE: That's right.

AUSTIN: (to SAUL) He's been camped out on the desert for three months. Talking to cactus. 
What's he know about what people wanna' see on the screen! I drive on the freeway every day. I swallow the smog. I watch the news in color. I shop in the Safeway. I'm the one who's in touch!

Not him!

SAUL: I have to go now, Austin. (Shepard 1981, p. 37)

It seems so interesting that, the binaries are, also, in Lee's true to life western. In his chasing story, the reader follows two lamebrains which chase each other across the desert and it is never revealed that who is the privileged one. The justification has been probably rooted in the lack of final signified.

So they take off after each other straight into an endless black prairie ... What they don't know is that each of' em is afraid, see. Each one separately thinks that he's the only one that's afraid ... And the one who's chasin' doesn't know where the other one is taking him. And the one who's being chased doesn't know where he's going. (Shepard 1981, p. 27)

Another binary, in which Lee and Austin are trapped in, is the opposition of 'hope' and 'hopelessness'. According to Roudane (2002), the sense of entrapment is something common to all Shepard's heroes. He states that characters find themselves;

struggling with their own distorted versions of objective reality, and trying to survive in an American landscape warped by its own deflected myths, generational schisms, and wayward sense of Manifest Destiny. (p. 2)

The binary of 'art' and 'reality' is another opposition in True West. Surprisingly, it is finally Lee who understands the distinction between fiction and reality while Austin doesn't. Lee's true western, which is finally going to be narrated by him and brought on paper by Austin, has been a means for Shepard to make True West more complex. In fact, Shepard complicates his story by placing the question of fictional characters in the mouth of fictional characters; because of these fictionalities, the search for truth seems almost impossible.

SAUL: I have to go with what my instincts tell me--

AUSTIN: Your instincts!

SAUL: My gut reaction.

AUSTIN: You lost! That's your gut reaction. You lost a gamble. Now you're trying to tell me you like his story? How could you possibly fall for that story? It's as phony as Hopalong Cassidy. What do you see in it? I'm curious.

SAUL: It has the ring of truth, Austin.

AUSTIN: (laughs) Truth?

LEE: It is true. (Shepard 1981, p. 37)

Effectively, Lee's chasing story reflects the relationship of the two brothers on stage, and therefore making his fictional script real. Another point regarding Lee's story is that the chase creates the illusions of some sort of meaning to men's meaningless existences; in fact the chase is a means to give men a sense of their true identity. According to Hall (1993):

This quest, too, is motivated by an absent woman, for the one man chases the other because he has been sleeping with his wife. Shepard's image,very poetically, summarizes Lacan's theories regarding the essential lack that characterizes human existence. Without the presence of a woman, the men are lost; ostensibly defending their rights, but finally the chase creates the illusions of some sort of meaning to their meaningless existences. In this image, the chase becomes the mirror by which the men attempt to gain a sense of identity. (p. 7)

\section{TRUE WEST: THE DECAY OF THE DISTINCTION BETWEEN HIGH AND LOW CULTURE}

In his discussion of postmodernism, Fredrick Jameson calls the mixture of what he considers high and low culture as one of the other features of the postmodern period. In fact, in modernism, literature and art should be viewed and valued in opposition to the popular culture because, in modernism, the emphasis is on the high art which seeks intellectual readers. However, as postmodernism is an eclectic school, there would be a mixture of high and low culture, while art is no longer a prerogative for intellectuals and is produced by anybody who is interested in and is made for all groups of people.

In True West, when Austin mentions that he has some business regarding the script with a Hollywood producer, Lee says: "I thought it was 'art' you were doin" (Shepard 1981, p. 14). For Lee, Austin is not the creator of the script, but someone engaging in related business not art. Through this, Shepard shows that art is no longer perceived as a form of high culture rather, it is something simply like business which is produced to attract the public.

In contemporary culture art does not demand "formal training or traditional form". It is simply "an expression of self" (Abbotson 2005, p.73). This is why a person like Lee can write a scenario into which attention is paid. This is, in fact, one of the contemporary American culture's fantasies which is brought by hollow promises of Hollywood. Saul 
Kimmer's primary concern, as a representative of Hollywood, is not to enhance the value of art, but to make more dollars. He simply gambles over Austin's script and when he finds Lee's Story more authentic to attract the public, he drops Austin's project which is a story about the universality of love. Saul says: "In this business we make movies, American movies. Leave the films to the French" (Shepard 1981, p. 30).

\section{Conclusion}

True West suggests so many interesting postmodern elements. The plot development, though appears to be logical, gradually becomes completely disorienting. Unresolved conflict between modernist and postmodernist perspectives is one dominant source tension in the course of the play; Austin and Lee, two feuding brothers, are in search of their identities and their past in a modern sense, completely unaware that past and all its ideals are gone with the wind, and a new postmodern atmosphere has pervaded the air.

The Lyotardian breakdown of the grand narratives, also known as metanarratives, is another Shepard's preoccupation in True West. In the play, the central action of the play is, in fact, a confrontation between the sons' outdated reliance on absolutes, on codes of behavior, and finally, on grand narratives. Austin and Lee's conflicts are rooted in yearning for a center. This center is sometimes supposed to be their father, and sometimes, it is the comfort of desert which can give them the true touchstone. But the fact is that there is no longer any center to stick to; everything is so unreliable and there is no real authority and no final meaning, in other words, there is no transcendental signified.

The sense of non-ending is another postmodern feature of the play. In True West, the action of the play goes nowhere, the reader or the audience comes to a dead-end, an 'aporia', because there are indefinite contradictory meanings or significations in the play, and it is not easy to decide, choose or even refer to the one as the final signified. Fragmentary pieces of the story never quite make sense, and any search for objective truth - whether by the character or by the reader - comes to failure. The play is structured less as chain of events, rather as collages and patchworks of dialogues, communication and confrontations. Thus, the reader or the audience finds himself deeply involved in a postmodern sense of fragmentation.

The existence of binary oppositions in True West reflects the postmodern environment of the play. Austin and Lee frequently change roles and reverse their places; so surface/depth model of personal identity, also, is a binary which continues reversing the personas of the brothers, and in none of them finds a privilege over the other.

Deconstruction of the text is also what Deride refers to, and is what happens in True West. The text of the play deconstructs itself as sometimes it is not clear who is chasing and who is being chased, whether the narrator, or the characters. Taking advantage of self-deconstructing feature of the text, Shepard parallels the situation of Austin and Lee with the two lamebrains of Lee's story and through this creates the effect of characters being trapped within textuality. At the same time, through this technique another feature is created, namely the 'self-reflexivity' of the text.

Thus, for Shepard, the entire postmodern world can be regarded as a stage, in which, characters come, get decentered, fragmented, and all of a sudden feel themselves in catch 22 from which there is no way out. And this is what he exactly did in True West.

\section{References}

Abbotson, S. C. W. (2005).Masterpieces of 20th-century American drama. Greenwood Publishing Group.

Andreach, R. J. (1998).Creating the Self in the Contemporary American Theatre. Carbondale, IL: Southern Illinois University Press.

Auslander, P. (2005). "Postmodernism and Performance" The Cambridge Companion to Postmodernism.Ed. Steven Connor. London: Cambridge University Press: 246-259.

Bottoms, S.J. (1998).The Theatre of Sam Shepard: States of Crisis. London: Cambridge University Press.

Couch, J. D. (2006). "Ending and Copping out: Completeness and Closure in the plays of Sam Shepard." Diss. University of Maryland, Collage Park.

Gilman, R. (1981). Introduction. Sam Shepard's Seven Plays. BY Sam Shepard. New York: Dial Press: xi-xxvii.

Hall, A. C. (1993). A Kind of Alaska: Women in the Plays of O'Neill, Pinter and Shepard. Carbondale: Southern Illinios University Press.

Hooti, N., \& Shooshtarian, S. (2010). Studies in Literature and Language, 1(7), 13-31.

Kane, L. (2002). "Reflections of the Past in True West and A Lie of the Mind." The Cambridge Companion to Sam Shepard.Ed. Matthew Roudane. London: Cambridge University Press 139-153.

Lewis, B. (2001). Postmodernism and Literature. In Stuart Sim (Ed.), In TheRoutledge Companion to Postmodernism. London: Routledge.

Lyotard, J.F. (1984). The Postmodern Condition: A Report on Knowledge. Geoff Bennigton and Brian Massumi (trans.). Manchester: Manchester University Press.

Mason, F. (2007). Historical Dictionary of Postmodernist Literature and Theatre. The Scarecrow Press.

McHale, B. (1987).Postmodern Fiction. London and New York, Routledge. 
Mcteague, J. H. (1996). Playwrights and Acting: Acting Methodologies for Brecht, Ionesco, Pinter, and Shepard. Westport, CT: Greenwood Press.

Murphy, P. D. (1992).Staging the Impossible: The Fantastic Mode in Modern Drama. Westport, CT: Greenwood Press. Roudane, M.(2002). ed. The Cambridge Companion to Sam Shepard. London: Cambridge University Press.

Saddik, A. J. (2007).Contemporary American Drama.Edinburg University Press.

Shepard, S. (1981).Sam Shepard Seven Plays. New York: Dial Press.

Shewey, D. (1997). “Sam Shepard's Identity Dance.”American Theatre.

Taylor, V. E., \& Charles E. W. (2001).eds. Encyclopedia of Postmodernism. London: Routledge.

Wade, L. A. (1962). "Sam Shepard and the American Sunset: Enchantment of the Mythic West."Masters of Modern Drama. Eds. Block and Shedd: Random House:285- 299.

Walmsley, S. C. (2006). "Postmodernism" An Oxford Guide: Literary Theory and Criticism. Ed. Patricia Waugh. New York: Oxford University Press.

Wessendorf, Ma. (2012). "Drama and/after Postmodernism". 28 Nov 2012. University of Hawai‘ $i$ at Manoa.http://www.hawaii.edu/ wessendo/Post911Drama.htm.

Wilcox, L. (1984). "Modernism vs. Postmodernism: Shepard's The Tooth of Crime and the Discourse of Popular Culture.” Modern Drama: 560-573. 